\begin{tabular}{|c|c|}
\hline & $\begin{array}{l}\text { International Journal of Trend in Scientific } \\
\text { Research and Development (IJTSRD) }\end{array}$ \\
\hline 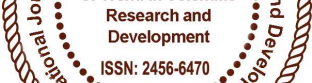 & International Open Access Journal \\
\hline 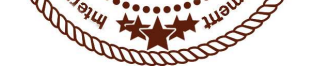 & ISSN No: 2456 - 6470 | www.ijtsrd.com | Volume - 2 | Issue - 2 \\
\hline
\end{tabular}

\title{
Scope of Parthenium hysterophorus L. and Acorus calamus L. as Biopreservative for Non-durable Wood Timber Species
}

\author{
Bandana Dhiman \\ Department of Forest Products, \\ College of Forestry, \\ Dr. Y. S. Parmar, University of \\ Horticulture and Forestry, Nauni, \\ Solan, Himachal Pradesh, India
}

\author{
Dr Kulwant Rai Sharma \\ M.Sc., Ph.D. (Forestry), Professor \\ and Head, Department of Forest \\ Products, Dr. Y. S. Parmar, \\ University of Horticulture and \\ Forestry, Nauni, Solan, \\ Himachal Pradesh, India
}

\author{
Y Y Sumtahne \\ Department of Forest Products, \\ College of Forestry, \\ Dr. Y. S. Parmar, University of \\ Horticulture and Forestry, Nauni, \\ Solan, Himachal Pradesh, India
}

\section{ABSTRACT}

In this study polyporus fungal decay reduction effect was shown on wood samples of Pinus roxburghii Sargent, Celtis australis L. and Bombax ceiba L. by using methanolic extract of Parthenium hysterophorus L and Acorus calamus L. These less durable wood samples were treated with different concentrations $(0.25 \%, 0.5 \%, 1 \%, 1.5 \%$ and $2 \%)$ $(\mathrm{w} / \mathrm{v})$ of both extracts. Fungus testing was done on the treated wood samples to evaluate efficacy of taken herbal extracts. Maximum fungus inhibition of $46.24 \%$ and $69.45 \%$ was found with extract of Parthenium hysterophorus L. and Acorus calamus L at $2 \%$ concentration. It was also found that specific gravity increased with increase in concentration with maximum at $2 \%$. Results had showed that both extracts inhibit fungus growth significantly and act as a good wood preservative.

Keyword: Acorus calamus L., preservative, fungal decay, Parthenium hysterophorus L.

\section{INTRODUCTION}

Wood is a cellular resource with excellent strength-toweight properties. It is easily produced composite material of botanical origin with unique structural and chemical characteristics that render it desirable for broad variety of end uses (Hingston et al., 2001). Being a biological material, non durable wood is more prone to be degraded by/biological agents than durable wood species. Knowledge about the natural durability of wood species can provide useful information on their possible end-uses as well as important predictions on product service life (Gambetta et al., 2004). The inherent ability of wood species to resist biological deterioration is referred as to natural durability or decay resistance (Johnson et al., 2006). Therefore, wood preservation is required after harvesting to reduce attack by wood deteriorating agents and ultimately enhance its durability. Conventional wood preservatives though effective against biodeterioration agents are costly, toxic and hazardous to the environment. Currently, the use of eco-friendly wood preservatives extend the life span of non-durable wood species which are now been used as a substitute for the scarce durable wood (Onuorah, 2000).

Parthenium hysterophorus L. (Congress grass) is an aggressive weed of family Asteraceae which is native to the subtropics of North and South America but now has invaded Asia, Africa and Australia during the last 50 years. The chemical analysis has indicated that all the plant parts including trichomes and pollens contain toxins called sesquiterpene lactones. The major components of toxin being 'parthenin' and other phenolic acids such as caffeic acid, vanillic acid, anisic acid, chlorogenic acid and parahydroxy benzoic 
acid are lethal to human beings and animals (Oudhia, 1998). Acorus calamus L. is a plant of perennial wetland monocot of Acoraceae family, commonly known as "bach"' and its roots, rhizomes and leaves have insecticidal properties. Different parts of the plant showed the presence of large number of phenyl propanoids, sesquiterpenes, monoterpenes, xanthone glycosides, flavones, lignans, steroids and inorganic constituents (Perrett et al., 1995). Beta-asarone in $A$. calamus rhizomes was demonstrated to have antibacterial activity (McGraw et al., 2002). A study has revealed that the $\beta$-asarone showed antifungal activity against Microsporum gypseum and Trichophyton rubrum than antibacterial activity.

An important and foremost parameter of physical property of wood is density or specific gravity which directly indicates the strength of timber. Wood density is the oldest and most widely used criterion for the evaluation of wood and is a measure of the amount of cell wall per unit volume (Barnett and Jeronimidis, 2003). Chemical modification in wood cell wall induces dimensional stability, $\mathrm{UV}$ resistance and biological resistance. Reaction of these chemicals with wood yields a modified wood with improved dimensional stability and higher density (Rowell, 2005).

Considering the importance of bio preservatives, the present work has been conducted with the objectives to test the potential of plants extracts against fungus growth and also to determine their efficacy as a wood bio-preservative for non durable wood species.

\section{MATERIAL AND METHODS}

Extraction and treatment to wood samples:Herbage of Parthenium hysterophorus L. (weed) and rhizomes of Acorus calamus L. (monocot medicinal Plant) were cut into small slices and chips, allowed to complete dry and then finely powdered and dried in the oven for 24 hours at $50 \pm 1^{\circ} \mathrm{C}$. Ground plant material then extracted with methanol using soxhlet apparatus on a boiling water bath. Then 2.5 litres stock solution of 10 per cent concentration is prepared by mixing with 5\% methanol. From this $10 \%$ stock solution different solutions of desired concentrations were made i.e., $0.25,0.50,1,1.50$ and 2 percent $\left(\mathrm{T}_{1}\right.$, $\mathrm{T}_{2}, \mathrm{~T}_{3}, \mathrm{~T}_{4}$ and $\mathrm{T}_{5}$ ) from both the extracts for treating the wood samples of Pinus roxburghii Sargent, Celtis australis L. and Bombax ceiba L. of size $5 \mathrm{~cm} \times 2.5 \mathrm{~cm}$ $\mathrm{x} 2.5 \mathrm{~cm}$ for 48 hours. Samples treated with distilled water were taken as control $\left(\mathrm{T}_{6}\right)$. All wood samples after treatment were oven dried at temperature $105^{\circ} \mathrm{C}$ up to a constant weight to find the wood specific gravity at different concentrations of the both extracts. The difference in weights, before and after treatment was taken as weight change in the wood samples to find specific gravity and was determined by the maximum moisture content method (Smith, 1954). The experiment was laid out in completely randomized block design with three replicates for each species and seven samples were used in each replication.

\section{Chromium treatment as preservative fixative}

Wood samples. which were treated with different concentrations (w/v) of Parthenium hysterophorus L. and Acorus calamus L. extracts were treated again with 5\% Chromium (VI) trioxide solution (chromic acid) for 2 hour to fix the extract. The treated wood samples were air dried for 4 hours and then placed in a pre-heated oven at $135 \pm 2{ }^{\circ} \mathrm{C}$ for 30 minutes. Chromium is a metal that occurs naturally in the environment in the form of metal-ores such as those containing iron and act as biological corrosion inhibitor which fixes the preservative in wood.

\section{Fungus Testing}

Wood rotting fungus i.e., Polyporus spp. was used to find the effect of extracts on fungus growth on treated wood samples. For the growth of fungus malt agar solid media was prepared directly by adding 2 per cent of malt and 2.5 per cent of agar in $1000 \mathrm{ml}$ distilled water. About $100 \mathrm{ml}$ of the medium was poured in air tight glass jars of $500 \mathrm{ml}$ and autoclaved at $15 \mathrm{lb}$ pressure per square inch (psi) for 20 minutes. Each treatment was replicated three times aseptically and allowed to solidify. The glass jars were inoculated with culture bits $(5 \mathrm{~mm})$ cut from 10 days old vigorously growing culture and the inoculated glass jars were incubated at $25 \pm 1^{\circ} \mathrm{C}$. Wood samples were sterilized by keeping them under UV light in Laminar Air Flow for 20 minutes prior to fungus decay tests. All instruments used under LAF were sterilized with alcohol then with spirit lamp to avoid contamination and for better results. Afterone month, fungus growth was accessed visually in all glass jars containing treated wood samples. Observations were recorded by comparing percent growth inhibition on treated wood samples of different concentrations with both extracts. Percent growth inhibition was calculated according to Vincent (1947) formula, 
$\mathrm{I}=$

C-T

$\mathrm{C}$

Where,

$\mathrm{I}=$ Per cent fungus growth inhibition;

$\mathrm{C}=$ Per cent fungus colonization in control;

$\mathrm{T}=$ Per cent fungus colonization in treated wood

\section{RESULTS AND DISCUSSION}

\section{Specific gravity}

The significant difference in specific gravity of wood among different species and treatments (Table 1). In Parthenium hysterophorus L. extract, maximum specific gravity of 0.576 was in Celtis australis L. and minimum (0.432) in Bombax ceiba L. Among the treatments, highest value of 0.533 was in $T_{5}(2.00 \%$ concentration) and the lowest value of 0.482 was in control $\left(\mathrm{T}_{6}\right)$. With treatment of Acorus calamus $\mathrm{L}$. rhizome extract, the maximum specific gravity of 0.586 was recorded in Celtis australis L. and minimum 0.465 in Bombax ceiba $\mathrm{L}$. The mean value of specific gravity for different treatments increases with increase in concentration of plant extracts and the highest at 2.00 per cent concentration (0.562) and lowest in control (0.499). The concentrations of both extracts have influence on the specific gravity of wood thereby affecting strength and durability. This may be due to the absorption of extract which enters the void spaces in the wood and results in higher specific gravity.

The interactions between species and treatments were significant. The highest specific gravity was in wood of Celtis australis L. at 2.00 per cent concentrations of Acorus calamus L. rhizome extract. The lowest specific gravity was in Bombax ceiba L. wood in control without any extract treatment. Similar findings have been reported by Usta and Hale (2006) by evaluation of wood specimens taken from a single Caucasian fir tree which indicated that density had a significant relationship with absorption. Tjeerdsma and Pfeiffer (2007) have reported that the average density of treated Accoya wood is more than the average density of untreated wood. Devi (2013) and Chauhan (2013) have also observed that at 2.00 per cent concentrations of Ageratum conyzoides L. and Melia azedarach L. extracts, specific gravity of wood samples was maximum than samples treated with extract concentration of $0.25 \%$.

Table 1: Specific gravity of treated wood samples with

Parthenium hysterophorus L. and Acorus calamus L. extracts

Parthenium hysterophorus $\mathrm{L}$. ${ }^{-} \mid \mathrm{O} / \mathrm{Acorus}$ calamus $\mathrm{L}$.

\begin{tabular}{|c|c|c|c|c|c|c|c|c|}
\hline Treatments & $\begin{array}{l}P . \\
\text { roxburgh } \\
\text { ii }\end{array}$ & $\begin{array}{l}\text { C. } \\
\text { australis }\end{array}$ & $\begin{array}{l}\text { B. } \\
\text { ceiba }\end{array}$ & $2456=6$ & $\begin{array}{l}P . \\
\text { roxburgh } \\
i i\end{array}$ & $\begin{array}{l}\text { C. } \\
\text { australis }\end{array}$ & $\begin{array}{l}\text { B. } \\
\text { ceiba }\end{array}$ & Mean \\
\hline $\mathrm{T}_{1}$ & 0.503 & 0.593 & 0.415 & 0.504 & 0.533 & 0.549 & 0.436 & 0.506 \\
\hline$T_{2}$ & 0.525 & 0.570 & 0.424 & 0.506 & 0.543 & 0.559 & 0.459 & 0.520 \\
\hline $\mathrm{T}_{3}$ & 0.534 & 0.574 & 0.431 & 0.513 & 0.550 & 0.606 & 0.476 & 0.544 \\
\hline $\mathrm{T}_{4}$ & 0.541 & 0.587 & 0.455 & 0.528 & 0.566 & 0.610 & 0.495 & $\mathbf{0 . 5 5 7}$ \\
\hline $\mathrm{T}_{5}$ & 0.577 & 0.555 & 0.466 & 0.533 & 0.574 & 0.615 & 0.498 & 0.562 \\
\hline $\mathrm{T}_{6}$ (control) & 0.488 & 0.556 & 0.403 & 0.482 & 0.497 & 0.576 & 0.423 & 0.499 \\
\hline Mean & 0.524 & 0.576 & 0.432 & & 0.544 & 0.586 & 0.465 & \\
\hline
\end{tabular}

\section{Fungus growth inhibition}

Maximum fungus growth inhibition of 47.60 and 75.00 per cent was observed in Pinus roxburghii using extract of Parthenium hysterophorus and Acorus calamus respectively. Among treatment mean wood fungus growth inhibition has been increased with increase in extract concentration in both cases i.e. 2.00 per cent concentration have maximum fungus growth inhibition and was minimum at 0.25 per cent with treatments of Parthenium hysterophorus L. and Acorus calamus L. extract. 
International Journal of Trend in Scientific Research and Development (IJTSRD) ISSN: 2456-6470

Table 2. Fungus growth inhibition (\%) of treated wood samples with Parthenium hysterophorus L. and Acorus calamus L. extracts

\begin{tabular}{|l|l|l|l|l|l|l|l|l|}
\cline { 2 - 9 } \multicolumn{1}{l|}{} & \multicolumn{4}{l|}{ Parthenium hysterophorus L. } & \multicolumn{4}{l|}{ Acorus calamus L. } \\
\hline Treatments & $\begin{array}{l}\boldsymbol{P} \text {. } \\
\text { roxburghii }\end{array}$ & $\begin{array}{l}\text { C. } \\
\text { australis }\end{array}$ & $\begin{array}{l}\text { B. } \\
\text { ceiba }\end{array}$ & Mean & $\begin{array}{l}\boldsymbol{P} \text {. } \\
\text { roxburghii }\end{array}$ & $\begin{array}{l}\text { C. } \\
\text { australis }\end{array}$ & B. ceiba & Mean \\
\hline $\mathrm{T}_{1}$ & 5.00 & 0.00 & 7.25 & 4.08 & 16.67 & 0.00 & 8.33 & 8.33 \\
\hline $\mathrm{T}_{2}$ & 14.00 & 9.50 & 20.00 & 14.50 & 25.00 & 8.33 & 16.67 & 16.67 \\
\hline $\mathrm{T}_{3}$ & 20.00 & 18.00 & 27.50 & 21.83 & 41.67 & 25.00 & 25.00 & 30.56 \\
\hline $\mathrm{T}_{4}$ & 39.45 & 29.80 & 45.00 & 38.08 & 50.00 & 33.33 & 58.33 & 47.22 \\
\hline $\mathrm{T}_{5}$ & 47.60 & 39.50 & 51.62 & 46.24 & 75.00 & 66.67 & 66.67 & 69.45 \\
\hline $\mathrm{T}_{6}$ (control) & 5.00 & 0.00 & 7.25 & 4.08 & 5.00 & 0.00 & 2.00 & 0.00 \\
\hline
\end{tabular}

Similar findings were reported by Astiti and Suprapta (2012) while analyzing methanol extract of Teak leaf, which significantly inhibited the fungal radial growth with concentrations $0.5 \%$ or_more (w/v), decreases with increase in concentration and can thus be considered as one of the alternatives to chemical wood preservatives for controlling the wood decay in Albizia falcataria. The methanolic and ethanolic extracts of Neem leaves were able to inhibit the growth of the test fungus at a concentration of 3.0 per cent as compared to acetone extract. The 3.0 per cent concentration of ethanolic extract showed the best performance against the test on various wood decaying fungi (Kabir and Alam, 2007). Natural products from plants such as Ageratum conyzoides, Ficus retusa, Lavandula pubescens, Lawsonia alba etc. have been evaluated and found to have great potentials as novel fungicide sources for controlling pathogenic fungi (Bazaid et al., 2010). Devi (2013) and Chauhan (2013) have also observed that at 2.00 per cent concentrations of Ageratum conyzoides L. and Melia azedarach L. extract have minimum fungus colonization in wood and proved to be a good bio preservative.

In this current study polyporus fungal decay reduction effect was observed by using methanolic extract of anxious weed i.e., Parthenium hysterophorus (whole herbage) and a medicinal herb i.e., Acorus calamus (rhizome). Therefore, herbal preservatives have safe effect on non durable wood for increasing their life span than chemical preservatives.

\section{REFERENCES}

1. Astiti N P A and Suprapta D N 2012. Antifungal activity of teak (Tectona grandis) leaf extract against Arthrinium phaeospermum (Corda), the cause of wood decay on Albizia falcataria (L.) Fosberg. ISSAAS Philippines 18: 62-69.

2. Barnett J R and Jeronimidis G 2003.Wood Quality and its Biological Basis. Blackwell Publishing Ltd., Oxford, UK.CRC Press LLC, USA and Canada 225p.

3. Bazaid S A and Nehal S E 2010. Assessment of the Bioregulatory Activity of the Leaf Juices of Higher Plants in Al-Taif, Saudi Arabia against Fusarium solani, Phytopthora spp. and Rhizoctonia solani. Archives of Phytopathology Plant Protection 43: 1064-1071.

4. Chauhan K 2013. Studies on wood characteristics using Melia azedarach L. leaves extract as a wood biopreservative. M.Sc. Thesis, Dr. Y. S. Parmar University of Horticulture and Forestry, Nauni (Solan) 74 p.

5. Devi N 2013. Studies on wood characteristics using Ageratum conyzoides L. extract as a wood biopreservative. M.Sc. Thesis, Dr. Y. S. Parmar University of Horticulture and Forestry, Nauni (Solan) 77 p.

6. Gambetta A, Susco D and Zanuttini R 2004. Determination of natural durability of larch wood (Larix decidua Mill.) from the Western Italian Alps. Holzforschung 58: 678-681.

7. Goktas O, Mammadov R, Baysal E, Duru, M E, Ozen E and Colak A M 2007. Application of extracts from poisonous plant, Nerium oleander L. 
as a wood preservative. African Journal of Biotechnology 6: 2001-2003.

8. Hingston A J, Collins C D, Murphy R J and Lester J N 2001. Leaching of chromated copper arsenate wood preservatives. Environmental Pollution 1: 53-56.

9. Johnson G C, Tornton J D, Trajstman A C and Cookson L J 2006. Comparative in ground natural durability of white and black cypresspines (Callitris glaucophylla and C. endlicheri). Australian Forestry 69: 243-247.

10. Kabir A H and Alam M F 2007. Reduction of Environmental Toxicity Through Eco-friendly Wood Biopreservative. International Research Group on Wood Preservation IRG/WP: 07-50243.

11. Kubo I and Taninguchi M 1988. Polygodial, an antifungal potentiator. Journal of Natural Products 51: 22-29.

12. McGraw L J, Jager A K and Van Staden J 2002. Isolation of $\beta$-asarone, an antibacterial compound from Acorus calamus in South Africa. South African Journal of Botany 68: 31-35.

13. Onuorah E O 2000. Short communication: The wood preservative potential of heartwood extracts of Milicia excels and Erythrophilum suaveolens. Bioresources Technology 75: 171-173.

14. Oudhia P 1998. Parthenium: A curse for the biodiversity of Chhattisgarh plain. In: Abstract National Research Seminar on Biochemical changes. An impact on Environment, RD Govt. PG College, Mandla (M.P.) 30-31 July 26p.

15. Parrett, Sheena and Whit field 1995. Antihelmithic and pesticidal activity of Acorus calamus. Annal of Plant Protection Sciences 20: 452p.

16. Rowell R M 2005. Chemical modification of wood. In: Handbook of Wood Chemistry and Wood Composite, Rowell R M (Ed.), Tayllor and Francis, CRC Press, USA. 381-420.

17. Smith D N 1954. Maximum moisture content for determining specific gravity of small wood samples. Forest Products Lab. USDA, Forest Service Rep. 2014p.

18. Tjeerdsma B F and Pfeidder E 2007. Dimensional stability of Accoya wood under different moisture conditions. Report code: 6.3.22.
19. Vincent J M 1947. Distortion of fungal hyphae in the presence of certain inhibitors. Nature 150: $850 \mathrm{p}$.

20. Usta I and Hale M D 2006. Comparison of the bordered pits of two species of spruce (Pinaceae) in a green and kiln dried condition and their effects on fluid flow in the stem wood in relation to preservation. Forestry 79: 467-475.

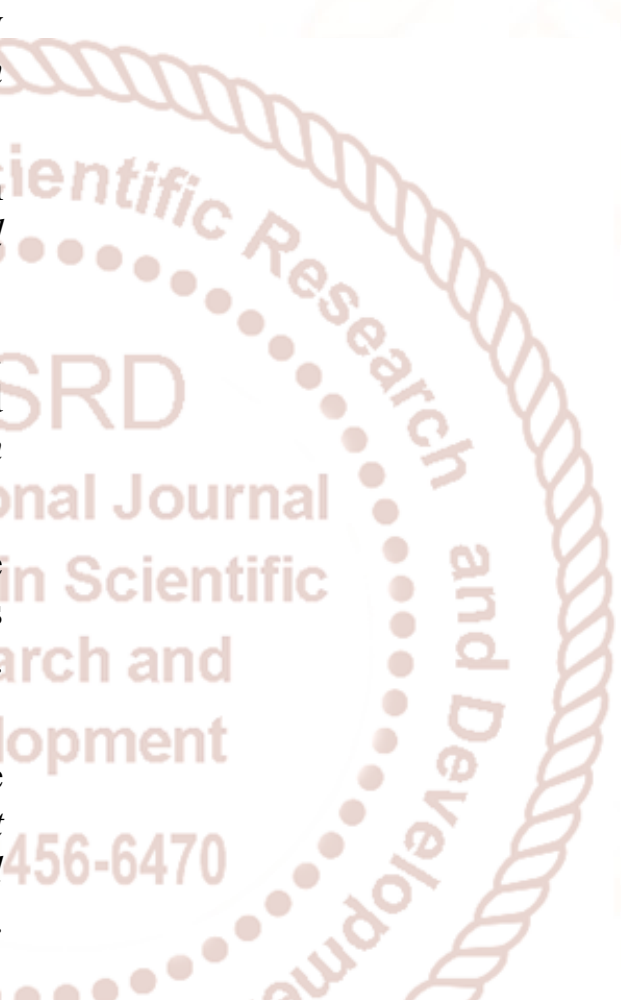

